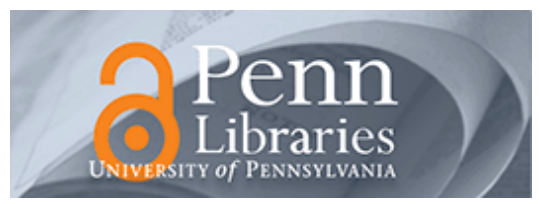

University of Pennsylvania

ScholarlyCommons

\title{
Global Equity Capital Markets for Emerging Growth Firms: \\ Patterns, Drivers, and Implications for the Globalizing Entrepreneur
}

\author{
Raphael Amit \\ University of Pennsylvania \\ Christoph Zott \\ INSEAD
}

Follow this and additional works at: https://repository.upenn.edu/mgmt_papers

Part of the Management Sciences and Quantitative Methods Commons

\section{Recommended Citation (OVERRIDE)}

Amit, R. \& Zott, C. (2004). Global Equity Capital Markets for Emerging Growth Firms: Patterns, Drivers, and implications for the Globalizing Entrepreneur. In H. Gatignon \& J.R. Kimberly (Eds.), The INDEAD-Wharton Alliance on Globalizing: Strategies for Building Successful Global Businesses (pp. 229-254). London: Cambridge University Press. [doi: 10.1017/CBO9780511522093.011] 


\title{
Global Equity Capital Markets for Emerging Growth Firms: Patterns, Drivers, and Implications for the Globalizing Entrepreneur
}

\author{
Abstract \\ The expansion and development of global financial markets has led to a rapid rise in foreign IPOs and \\ listings. As the opportunities for financing ventures have increased significantly, so has the complexity of \\ decisions facing entrepreneurs and others who need to tap into these markets. When equity can be \\ sourced virtually anywhere in the world, how do managers make decisions about listing a German firm on \\ the Neuer Markt, Nasdaq, or both? The authors draw upon academic literature and their own research on \\ foreign IPOs on US and German exchanges, as well as interviews with senior executives at firms that \\ chose to list on a foreign exchange. This chapter summarizes some of the key benefits that attract \\ companies to list on foreign exchanges, including gaining access to capital, offering liquidity to existing \\ investors, enhancing the company's reputation at home and abroad, providing currency for acquisitions in \\ the foreign country, offering exit opportunities, dispersing ownership geographically, and achieving a \\ higher valuation. Against these benefits, they present a set of costs, including underpricing and dilution, \\ direct costs of the IPO, reporting requirements, and recurring costs. By weighing these costs and benefits \\ entrepreneurs can develop informed strategies for taking advantage of globalizing equity markets.

\section{Disciplines} \\ Management Sciences and Quantitative Methods
}




\title{
10 Global equity capital markets for emerging growth firms: patterns, drivers, and implications for the globalizing entrepreneur
}

\author{
RAPHAEL AMIT \\ Wharton School \\ CHRISTOPH ZOTT \\ INSEAD
}

The expansion and development of global financial markets has led to a rapid rise in foreign IPOs and listings. As the opportunities for financing ventures have increased significantly, so has the complexity of decisions facing entrepreneurs and others who need to tap into these markets. When equity can be sourced virtually anywhere in the world, how do managers make decisions about listing a German firm on the Neuer Markt, Nasdaq, or both? The authors draw upon academic literature and their own research on foreign IPOs on US and German exchanges, as well as interviews with senior executives at firms that chose to list on a foreign exchange. This chapter summarizes some of the key benefits that attract companies to list on foreign exchanges, including gaining access to capital, offering liquidity to existing investors, enhancing the company's reputation at home and abroad, providing currency for acquisitions in the foreign country, offering exit opportunities, dispersing ownership geographically, and achieving a higher valuation. Against these benefits, they present a set of costs, including underpricing and dilution, direct costs of the IPO, reporting requirements, and recurring costs. By weighing these costs and benefits entrepreneurs can develop informed strategies for taking advantage of globalizing equity markets.

The authors contributed equally to this chapter. Raffi Amit acknowledges the generous financial support of the Wharton e-business research center (a unit of WeBI), the Snider Entrepreneurship Research Center, and the Robert B. Goergen Chair in Entrepreneurship at the Wharton School. Christoph Zott gratefully acknowledges financial support from INSEAD. Both authors thank Iwona Bancerek and Amee Kamdar for their excellent research assistance, and Stacey Lange for her support. We thank the participants in the INSEAD workshop held during the development of this study for their insightful comments. 
I

$\mathrm{N}$ recent years, a new trend in the capitalization of relatively young, growth-oriented firms has emerged. These firms can now access foreign public equity capital markets. That is, these firms can raise funds in public capital markets in countries other than the ones where they were originally incorporated and headquartered. For example, Infosys Technologies Ltd., a global IT services company was the first Indian firm to be listed on the Nasdaq stock market. The Israeli company Check Point Software Technologies, which is the market leader in Internet security and firewall systems, had its initial public offering (IPO) on Nasdaq, and was added to the Nasdaq 100 index in 2000. Similarly, Lycos Europe NV, based in Holland, went public on the Neuer Markt in Germany.

While research on the globalization of public equity markets for financing entrepreneurial firms is only beginning to appear, ${ }^{1}$ there has been an increase in non-domestic IPOs on both Nasdaq in the United States and the Neuer Markt in Germany. Since 1988, there have been 405 IPOs on the Nasdaq by non-domestic firms from 44 different countries, raising $\$ 50.35$ billion of equity capital, or, on average, $\$ 125.5$ million per issue. These non-domestic IPOs represented 8 percent of the total number of IPOs on Nasdaq between 1988 and 2001, and accounted for 19.5 percent of the equity capital raised by all IPOs on Nasdaq in that period. On the other hand, the younger Neuer Markt had a total of 313 IPOs, of which 44 (or 14 percent) were non-domestic. The non-domestic issuers raised $\$ 4.5$ billion on the Neuer Markt, averaging \$102 million per IPO.

As the total number of IPOs on Nasdaq grew, so did the number of foreign listings - from three non-domestic listings on Nasdaq in 1988 to thirty-four in 1998 and seventy-eight in 2000. These non-domestic listings amounted to 2 percent of the total number of companies listed in 1988 , growing to 12 percent in 1998 and 19 percent in 2000, before dropping to about 9 percent in 2001. The growth of foreign listings even outpaced the overall growth of the IPO market. While the overall IPO market grew at a compound annual growth rate (CAGR) of 5.9 percent from 1988 to 1998, and 7.5 percent from 1988 to 2000, nondomestic listings grew at CAGRs of 24.7 percent and 28.5 percent respectively. $^{2}$

This trend in the globalization of the public equity market for entrepreneurial finance, which has been mirrored in the simultaneous globalization of private equity markets, is particularly interesting as these markets are notoriously plagued by the presence of asymmetric 
Nasdaq 1988-2001

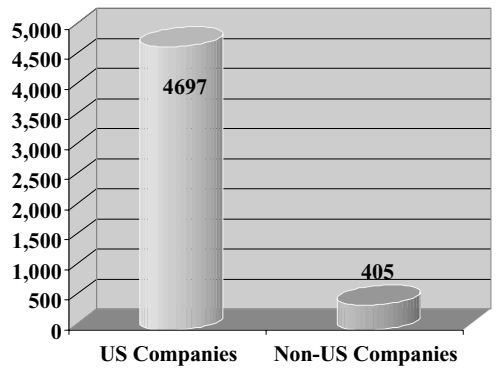

$8 \%$
Neuer Markt 1997-2001

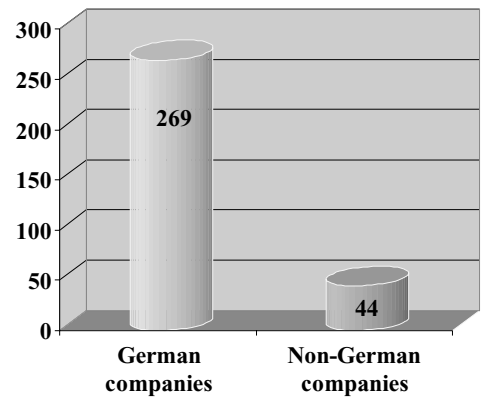

$14 \%$

Figure 10.1. Domestic vs. non-domestic IPOs.

information (moral hazard, adverse selection). With foreign firms, the possibility of asymmetric information is heightened. As a result, the question of why markets for public entrepreneurial finance globalize so rapidly is interesting both theoretically and empirically. What can help explain this phenomenon? And what are the implications of these trends for the globalizing entrepreneur and for the leaders of corporate ventures? To illuminate one significant factor in the formation and rapid growth of entrepreneurial firms throughout the world, these are the questions that will be addressed in this chapter.

The next section examines patterns of globalization of equity capital markets as they affect entrepreneurial firms. We then consider the drivers and the tradeoffs inherent in globalization, examined through the perspective of entrepreneurial firms. We conclude with a section on implications for entrepreneurs of the globalization trend in capital markets.

\section{Patterns of non-domestic IPOs}

As noted above, our research shows that foreign IPOs - those by firms that have an original country of incorporation that differs from the country where their securities are listed - have increased on both the Nasdaq stock market in the United States and on the Neuer Markt (NM) in Germany (see Figure 10.1). ${ }^{3}$ We focus on Nasdaq, which began trading in February 1971 (see Figure 10.2 for its evolution), because it is the largest and most developed market for high-growth firms. We also chose the Neuer Markt, which was established in March 
1971 On February 8, Nasdaq begins trading.

1984 Small Order Execution System ${ }^{\mathrm{SM}}$ becomes ready for use to execute small orders automatically against the best quotations - making greater volume and efficiency in trading possible.

1994 Nasdaq surpasses the New York Stock Exchange in annual share volume.

1998 In conjunction with the Stock Exchange of Hong Kong, Nasdaq announces a partnership to provide investors worldwide with information about their respective markets on a new, joint Internet web service.

1999 Nasdaq becomes the largest stock market in the United States by dollar volume and repeatedly breaks share and dollar volume records. In June, Nasdaq signes an agreement in Tokyo with Softbank Corporation, jointly capitalizing a new company - Nasdaq Japan $^{\mathrm{SM}}$. This proves to be the first leg in Nasdaq's global strategy to link Asian markets with European and American markets.

2000 The restructuring spins off Nasdaq into a shareholder-owned, for-profit company. Nasdaq completes the first phase of its restructuring. Nasdaq formally opens the new Market Site in the heart of New York's Times Square. Nasdaq continues to be the engine for capital formation and job creation. Between 1997 and 2000 , it has brought 1,649 companies public, and in the process raised $\$ 316.5$ billion. Nasdaq continues to build capacity for the trading volumes of tomorrow, with a capacity to trade 6 billion shares a day, a tenfold increase since 1997.

Figure 10.2. Evolution of Nasdaq. (Source: Nasdaq)

1997 (see Figure 10.3), because it was the largest and most liquid market in Europe for emerging growth companies during the time period we consider. (In 2002, it was merged back into the Deutsche Börse, following the collapse of the market for technology IPOs.)

Foreign companies accounted for 8 percent of IPOs on Nasdaq between 1988 and 2001, and represented 14 percent of offerings on the Neuer Markt between 1997 and 2001. While there has been variability in the percentage of non-domestic listings on both exchanges, there was a steady increase in the percentage of foreign listings until 2000 on Nasdaq and until 1999 on the Neuer Markt (see Figure 10.4). In 


\begin{tabular}{ll}
\hline \hline Origin & In March 1997, Deutsche Börse AG (the entity operating the \\
& FSE) established a new trading platform within the \\
& Freiverkehr segment, called the Neuer Markt. \\
Target & It serves small to medium-sized innovative growth companies, \\
& in particular in the telecom, Internet, multimedia, \\
& entertainment software, biotech, and other high-tech areas. \\
Performance & The Neuer Markt by far outperformed the other market \\
& segments and contributed significantly to the increase in IPO \\
& activity in Germany. It attracted more than 320 issuers, some \\
& 20 percent of which are foreign. \\
Platform & It has not only become Europe's largest market for IPOs of \\
& German innovative growth companies, but also a platform \\
for high-tech companies from other European countries, \\
Israel and the United States.
\end{tabular}

Figure 10.3. Neuer Markt.

2000, while there was a 27 percent decline in Nasdaq's domestic IPOs from the preceding year, non-domestic IPOs jumped 50 percent. The seventy-eight non-domestic IPOs - an all-time high for a single year accounted for more than 19 percent of the total IPOs on Nasdaq in 2000 .

While a few countries dominate each exchange, Figure 10.5 shows the increasing geographic diversity of countries listed on both Nasdaq and the NM (although it does level off in 2000). This trend points to the increased receptiveness of investors on both exchanges to embracing innovative companies from around the world, despite the greater asymmetry of information about these non-domestic companies. It provides evidence of the true globalizing nature of equity capital markets for promising entrepreneurial firms.

\section{Drivers}

These patterns of increasing use of non-domestic capital markets by entrepreneurial firms are driven by some of the broader trends toward globalization outlined in the introduction to this book. First, the liberalization of capital markets along with a general harmonization of regulations, such as capital market regulations, taxes, etc., clearly 
Nasdaq

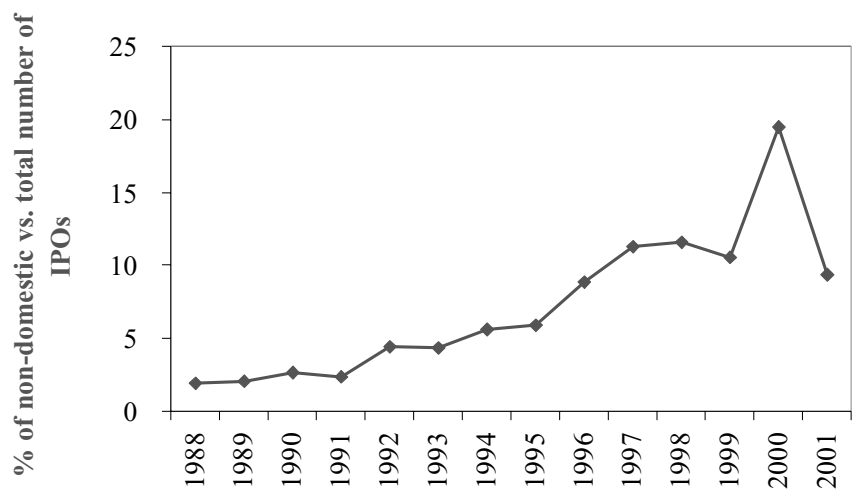

Neuer Markt

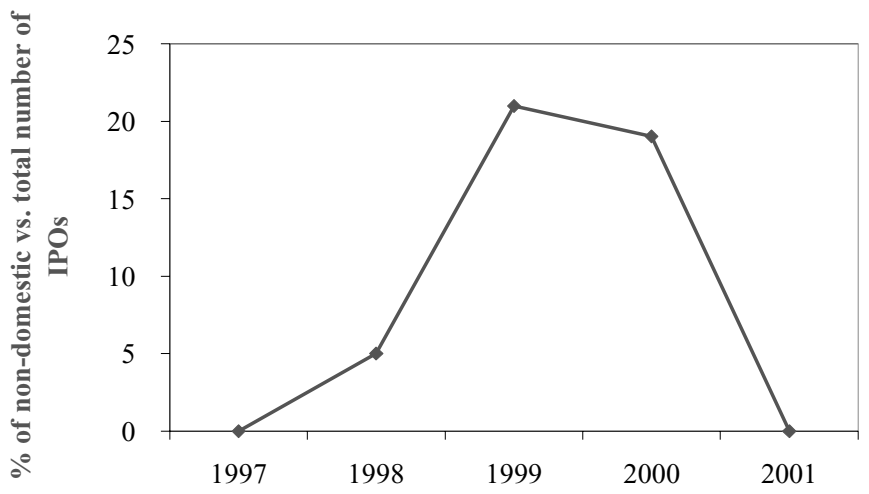

Figure 10.4. The increasing share of non-domestic IPOs on Nasdaq and the Neuer Markt.

foster cross-border flows of capital to support entrepreneurial companies. The creation of a common currency for the European Union, for example, reduced both currency risk and administrative barriers to investing, thereby facilitating cross-border investment in private local firms by non-local investors, both from within and outside the European Union. Second, rapid advances in technology and accelerating information flows make the investment process more efficient by enabling investors to meet their information needs and transact business at reduced cost. For example, firms can disseminate information to investors and analysts using teleconferencing technology, which 

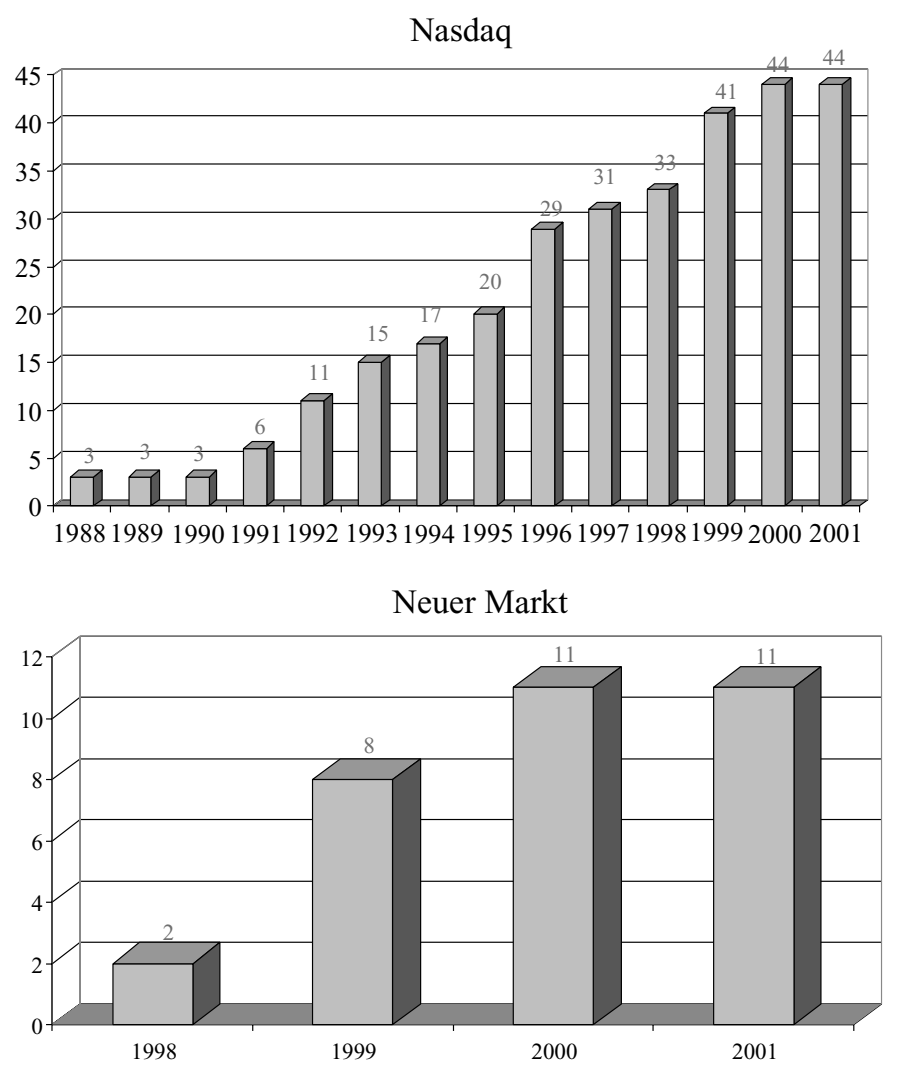

Figure 10.5. Number of foreign countries represented on Nasdaq and the Neuer Markt (cumulative IPOs). Note: Does not take into account delistings.

helps the latter avoid travel costs. Third, the trend toward an increased mobility of products implies that local firms are selling greater fractions of their output on global markets, which in some cases necessitates an enhanced presence in the foreign markets. One strategic rationale for raising funds in foreign markets, therefore, can be to improve a firm's visibility and brand recognition.

\section{Some surprising findings}

While the overall increase in foreign listings may be expected in the context of a globalizing world, there are some surprising findings from these data. 
Many foreign listings come from countries with healthy domestic exchanges: These foreign IPOs spanned a wide range of countries of origin in both markets, as shown in Figures 10.6 and 10.7. By the end of 2001, there were forty-four non-US countries represented on the Nasdaq. Three countries, in particular, accounted for 53 percent of listings by foreign firms between 1988 and 2001: Israeli companies had 86 IPOs, Canadian companies had 73 IPOs, and UK companies had 54 IPOs. As shown in Figure 10.6, there was a total of 44 nonGerman companies from ten countries that listed their IPOs on the Neuer Markt; four countries accounted for 70 percent of these nondomestic IPOs: Austrian companies had twelve, US companies had five, and Israeli and Dutch companies had seven each.

This raises some interesting questions. Why would so many Canadian and UK firms find it advantageous, despite the high cost associated with such offerings, to list on Nasdaq even though there are well-developed capital markets in their home countries? Why would some US firms choose to list on the NM, despite having the most developed capital market for emerging growth firms at home?

The average age of foreign companies on the NM is less than that of their domestic peers, yet these younger firms have a higher average market cap: Another surprising finding is that the average age of foreign companies that list on the NM is less than the average of the German companies that list there, and these younger companies have a higher average market cap. The age of non-domestic firms on the Neuer Markt averages 9.7 years compared to 12 years for their German peers. ${ }^{4}$ Investors faced with greater uncertainty about non-domestic companies might be expected to look for older firms with more historical data to compensate for the greater asymmetry of information. But this caution is absent, and there is no evidence of reluctance to make large investments in these younger companies, as might be expected. Quite the opposite. By comparing the average market capitalization to the age of the listing company, we observe an inverse relationship: the younger the company, the higher its market capitalization on the NM. Again, this is surprising, as investors have less historical information about younger companies. The fact that their capitalization is higher may reflect higher expectations about their future earning potential. 


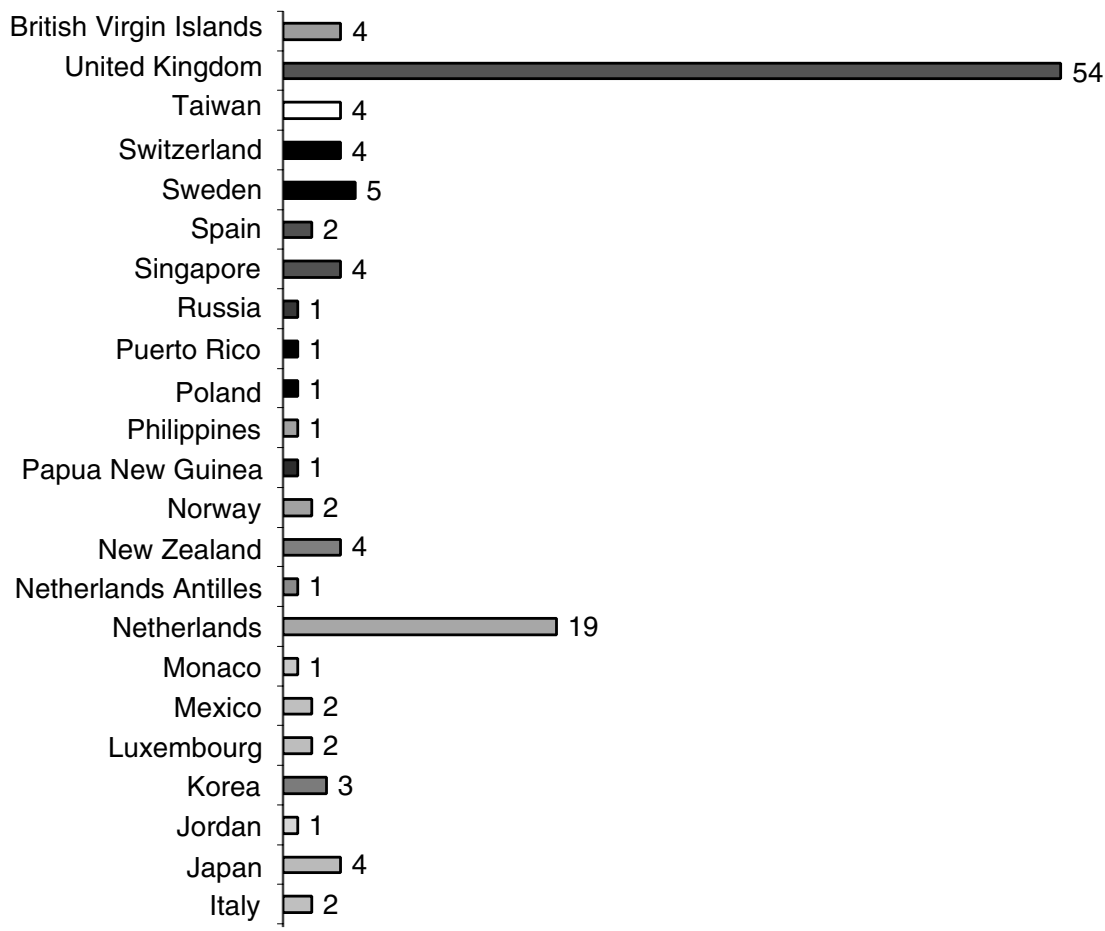

Figure 10.6. Number of non-domestic IPOs on Nasdaq by country of origin (cumulative number of listings for the period 1988-2001). 


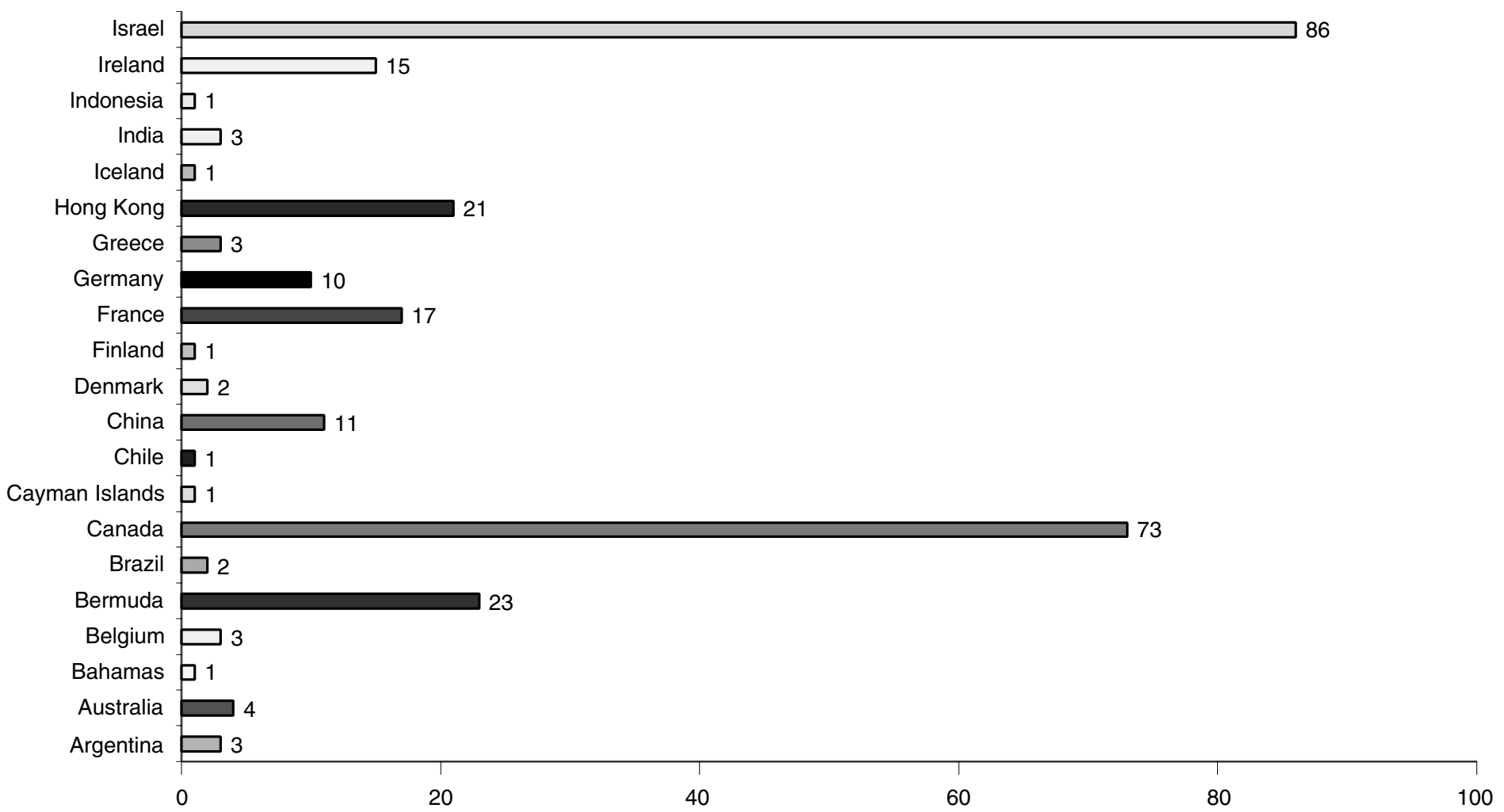

Figure 10.6. (cont.) 


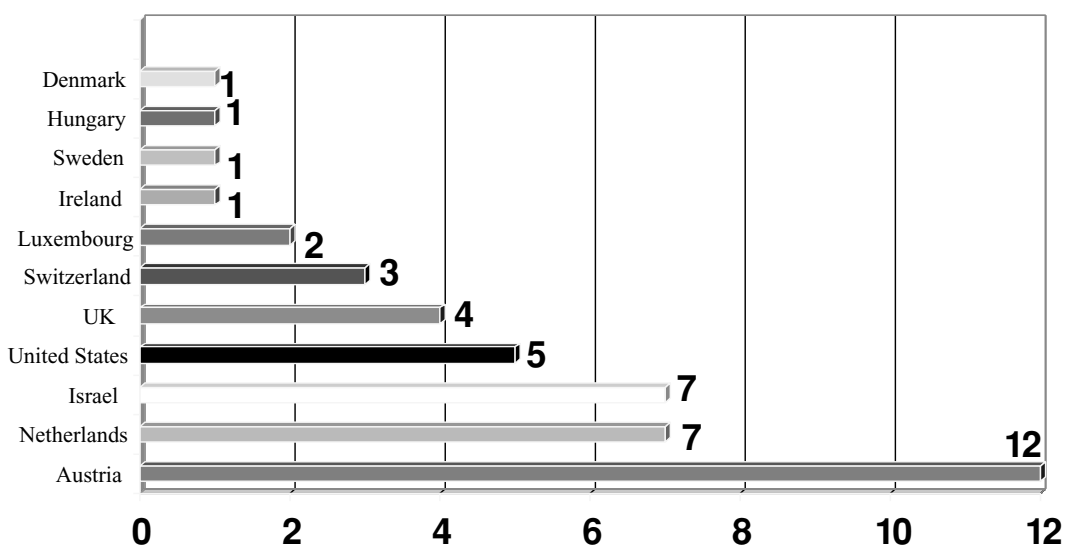

Figure 10.7. Number of non-domestic IPOs on the Neuer Markt by country of origin (Cumulative number of listings for the period 1997-2001).

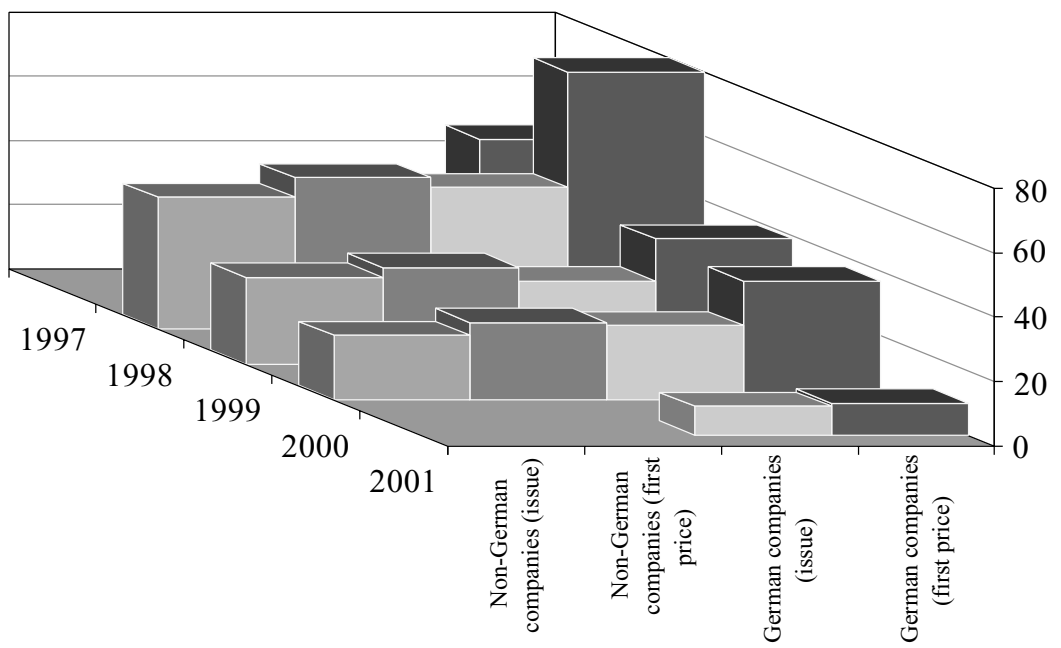

Figure 10.8. Issue price vs. first price (average), Neuer Markt, 1997-2001.

The "IPO discount" is not as steep for foreign firms: One of the costs associated with an IPO is the so-called "IPO discount," namely the issue price versus the closing price on the first day of trading. ${ }^{5}$ We would expect non-domestic firms to suffer a steeper discount owing to the higher potential for asymmetry of information, but we found the opposite on the NM. From 1997 to 2000, the percentage difference 


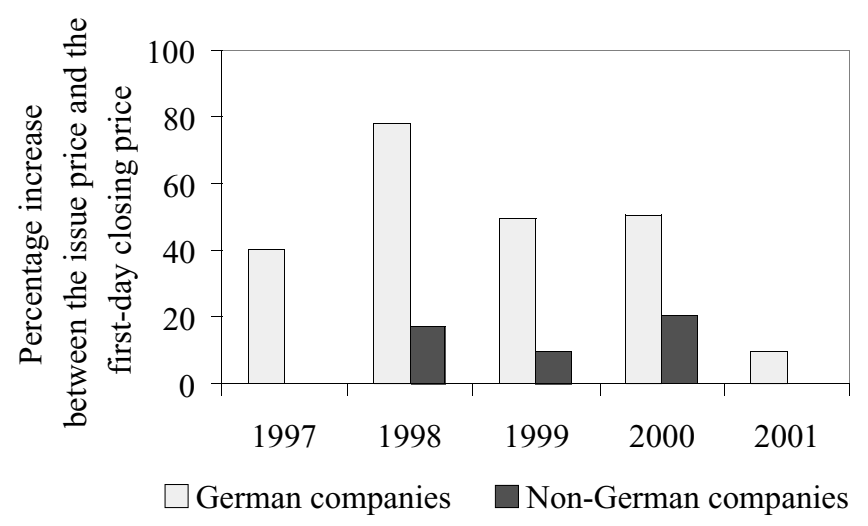

Figure 10.9. Percentage difference between the issue price and the first price, Neuer Markt, 1997-2001.

between the issue price and the closing price on the first trading day for non-domestic firms was smaller than for domestic firms (see Figures 10.8 and 10.9). This is particularly puzzling, as foreign firms on the NM, on average, are younger than domestic firms at the time of IPO.

Possible explanations could include the geographic dispersion of buyers. If the preference of German investors is to buy German stock rather than the stock of foreign companies, and if this preference is not anticipated by the bankers who price the new issue, greater underpricing of domestic firms may result. Similarly, on the Nasdaq, we also found that non-domestic firms have a smaller percentage difference between the issue price and the closing price on the first trading day than domestic firms (see Figures 10.10 and 10.11).

\section{Globalizing entrepreneurs: weighing the benefits and costs}

What implications do these data and patterns have for entrepreneurs faced with the complex decision of where to conduct an initial public offering for their companies? The entrepreneur who wanted to raise public equity before the 1980s faced a relatively straightforward decision - an IPO at home (if there was a home market for young, entrepreneurial firms at all). Today, the opportunities are more diverse, making costs and benefits harder to assess. Should this entrepreneur stick to home markets or take the company's roadshow across borders 


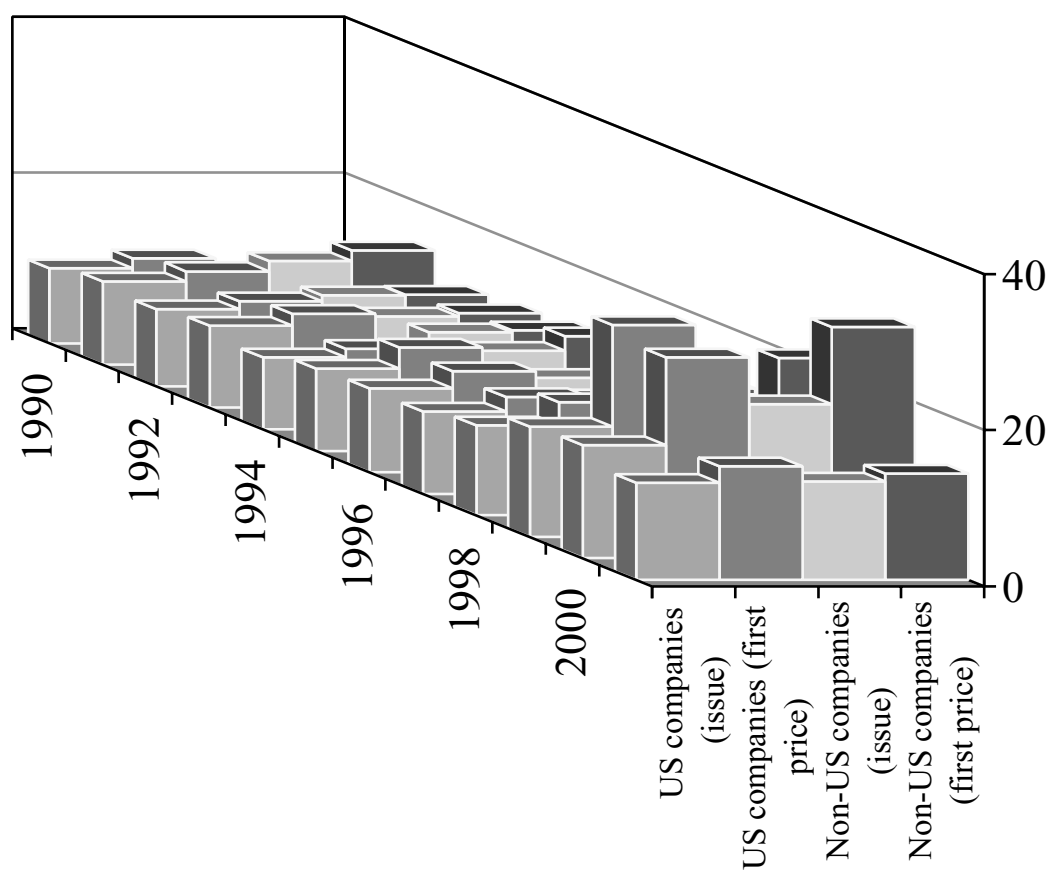

Figure 10.10. Issue price vs. first price (average), Nasdaq, 1990-2001. (Note: Analysis excludes seven companies for which first-price data are not available.)

to another market? How is this offering likely to be received at home and in the foreign market? There are no simple answers to this complex question, but by identifying the relative costs and benefits of sticking close to home or taking the offering abroad, managers can more fully analyze and weigh such decisions.

In the following subsections, we explore these costs and benefits in more detail. This discussion is informed by both the empirical research discussed above and academic literature, and is complemented by our own field research, including a questionnaire completed by senior executives of foreign firms that listed on the Neuer Markt. ${ }^{6}$

Benefits to entrepreneurs of listing their firms on a foreign exchange

Why have so many Canadian and British entrepreneurs taken their IPOs to Nasdaq? What are US and Israeli companies doing on the Neuer Markt? Many of these non-domestic companies are attracted to 


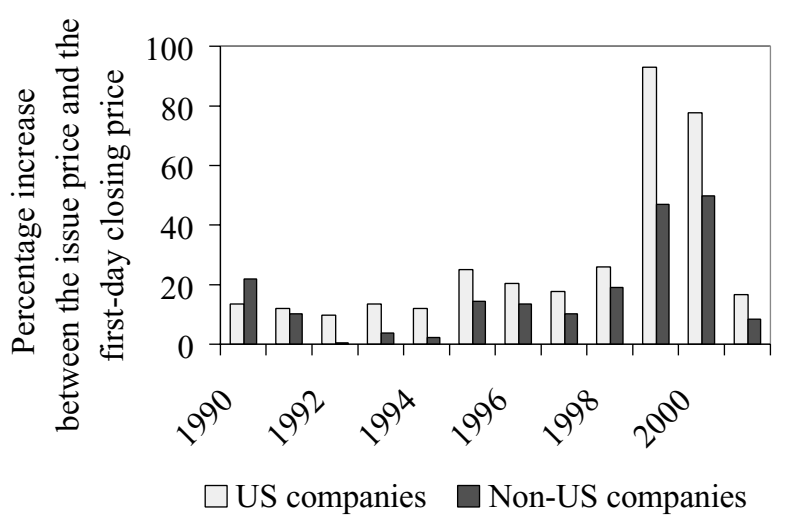

Figure 10.11. Percentage difference between the issue price and the first price, Nasdaq, 1990-2001. Note: Analysis excludes seven companies for which firstprice data are not available.)

the various benefits of listing on a foreign exchange. Seven of these are discussed here.

\section{Access to equity capital}

First and foremost, entrepreneurs raise funds because they need capital to build and grow their firms, organically or by acquisition. Considering their need for significant cash infusions, entrepreneurs are more likely to consider a foreign listing when the amount of money they can expect to raise in the foreign market is higher than in their local capital market. In one particular case, for instance, a firm with founders who were citizens of a foreign country chose to list in that country because "the bankers felt that because of [their] roots and [their] expansion goals [they] could make a significant investment case," thus increasing the firm's odds of raising much needed capital.

However, it may be more difficult for entrepreneurial firms to gain access to foreign capital markets due to asymmetric information problems. Investors buying shares in these markets may find it more difficult to obtain, interpret, or evaluate relevant information on the company's management, products, services, and markets. As a result, the greater asymmetry of information about non-domestic firms tends to drive up the cost of capital for the entrepreneurial firm which attempts to list its securities on public non-domestic capital markets. 


\section{Liquidity for existing investors}

Existing investors, including founders, senior managers, and employees who own stock (options), might wish to cash out some of their vested holdings in the company during its IPO and also in future rounds. (An IPO usually opens up the door for secondary offerings at some later point in time.) This "need for liquidity" argument is important in bull markets when the valuations of entrepreneurial firms are high. It also can be true in bear markets when investors may experience cash shortages or downright crises, and thus develop a preference for liquidity. To the extent that foreign capital markets offer a better chance to conduct a successful IPO (for example, because the local IPO market suffers from bad local economic conditions), entrepreneurs may prefer to list on a foreign exchange rather than on a local exchange.

Company shares and stock options are also an important incentive for employees and entrepreneurs to perform well. In general, the better the chances for a successful liquidity event such as an initial public offering, the more effective these incentives. Moreover, while existing strategic or financial investors may appreciate the possibility of liquidity, entrepreneurs may appreciate the opportunity to regain control of their firms ${ }^{7}$ or to avoid control by private investors such as venture capitalists. Entrepreneurs might also benefit from a greater volume of transactions in a foreign market, as that tends to increase the market capitalization of the company and thereby reduce transaction dilution of the entrepreneurs at the IPO (see the discussion of valuation below).

\section{Reputation, publicity, and visibility for entrepreneurial firms, abroad} and at home

While Jay Ritter and Ivo Welch surmise that in general these factors play "only a minor role for most firms," ${ }^{8}$ in the particular case of non-domestic entrepreneurial firms trying to get a foothold in foreign product and/or factor markets, these considerations can be important. Our data indicate that strategic reasons motivate many entrepreneurial companies to list on non-domestic markets. They strongly desire to increase their reputation and build their presence in the foreign market in which they have chosen to list. This motivation for foreign listing has been confirmed in a number of interviews with executives. Executives of the Austrian company AT\&S, which listed on the Neuer Markt in July 1999, suggested they chose the German market over the Austrian market because it enhanced the company's prestige and international 
visibility, which helped it to recruit highly specialized foreign technicians to positions in the company. A similar argument was made by Highlight Communication, a Swiss company that listed on the NM. Its leaders claim the listing allowed it to expand faster by increasing its visibility and reputation. The Israeli company On Track Innovation chose to list on the NM since it considered Germany to be its most important market and consequently wanted to have increased visibility there. Firms that listed outside their country of origin were able to make useful contacts in the foreign markets, became better known, gained prestige, increased their visibility and public relations, improved their familiarity with the foreign product markets, and eventually increased their sales and market share.

The challenge for most entrepreneurial firms is to overcome the liabilities of smallness and newness, ${ }^{9}$ which may be even more complicated in foreign markets, where a lack of track record and trading history may weigh heavily against non-domestic entrepreneurial firms. Foreign firms that want to establish credibility and legitimacy with potential customers, suppliers, investors, employees, or creditors may wish to do so by listing on the exchange of the target country, thus signaling their trustworthiness, quality, and commitment to establish a long-term presence in the market.

These moves not only enhance the company's reputation in foreign markets, but also can add to its image at home. Some firms use a foreign listing to create a corporate identity as an international company and avoid being perceived as a local player. They reasoned that significant market opportunities lay outside their local product markets, and these could be captured only by expanding the firm internationally. These firms wanted to create an image that was consistent with their expansion strategy. A related, but slightly different motive for foreign firms to list on the Neuer Markt, for example, was to associate themselves with the leading "new economy" exchange in Europe. They reasoned that they would benefit from a reputation spillover and therefore would be perceived as high-tech companies.

Interestingly, our qualitative interview data show that domestic firms may benefit from being listed on a foreign exchange if their objective is to acquire other domestic firms. Having an internationally recognized brand can enhance the perception of the company by domestic players as a reliable and valuable partner.

Companies also sometimes move to foreign markets to keep up with rivals. For example, a Swiss firm decided to raise equity capital on the 
Neuer Markt because "our competitors were on the Neuer Markt." It was presumably necessary to create a perception of competitive parity for customers, investors, and partners. These reasons for listing on a foreign exchange have not received much attention in either the finance or entrepreneurship literature to date.

\section{Currency for acquisitions}

Many firms that went public in the late 1990s pursued aggressive acquisition strategies, using their own company's shares, rather than cash, as a currency for acquisitions. ${ }^{10}$ This tactic is particularly attractive for entrepreneurial, high-growth firms as it preserves cash reserves needed to fuel the company's growth. Of course, the prerequisite for success of such a financing approach is for the acquiring firm to be publicly listed, as the shares of private companies commonly trade at a significant discount relative to comparable public firms. This argument becomes particularly relevant for entrepreneurial firms that intend to acquire firms in a foreign market where the shares listed on their home exchange (e.g. Korea) might not be considered a valid currency. This would provide an incentive to firms focused on growth through acquisitions in foreign markets to list their shares in these markets.

\section{Exit opportunities}

Listing on a foreign exchange might increase the awareness of potential foreign acquirers of an entrepreneurial firm, while at the same time improving the target firm's bargaining position. This is because acquirers cannot exert pressure as easily on outside investors as on privately held firms. ${ }^{11}$ In addition, the public market valuation puts a floor on the sales price, and the acquirer may actually have to pay a premium to convince public shareholders to take up the tender offer. An entrepreneurial firm might look at listing on a foreign capital market as possibly increasing the expected benefits from a trade sale in two ways: first, the decision to list on a foreign capital market may increase its chances of appearing on the radar screen of potential foreign acquirers; and, second, listing on the foreign market may result in a higher valuation than it would have had in its domestic capital market.

\section{Dispersion of ownership}

Increased dispersion of ownership may be attractive to entrepreneurs for several reasons. First, as Thomas Chemmanur and Paolo Fulghieri point out, diversified investors are generally willing to pay a higher 
price for a firm's shares than non-diversified investors, such as angel investors (i.e. individuals who invest their own money in privately held firms) or venture capitalists (i.e. institutional investors who invest other people's money in privately held companies). ${ }^{12}$ Second, entrepreneurs may find it easier to deal with a more dispersed ownership base where no single shareholder wields too much power.

The two advantages mentioned above hold for all publicly listed firms when compared with privately held firms. Listing on a foreign market offers the added benefit of having a geographically dispersed shareholder base, which may reinforce the aforementioned advantages. It might also reduce volatility in the stock price because of differential patterns of behavior of cross-cultural investors in response to events in the company. Thus, an Israeli firm going public in the United States may benefit, for example, from having both American and Israeli shareholders - two different groups of investors who may respond differently to important events. The decision may also offer the American investors an opportunity for geographic diversification.

\section{Valuation}

Listing on a foreign exchange offers the possibility of achieving a higher valuation than might be possible in a domestic market. That is true if the foreign exchange has higher liquidity or if the entrepreneurial firm attracts international institutional investors to which it otherwise would not have access, thus increasing the demand for its shares. A higher valuation implies less dilution for the entrepreneurs when they raise new funds, and decreases the firm's costs of raising new funds.

\section{Primary motives for foreign listings}

Our survey results revealed that the most popular motive for these firms to list on a foreign exchange was to raise equity (100\%), followed by strategic considerations to increase publicity and visibility (60\%), and the desire to have access to international investors in order to increase the geographic dispersion of ownership (33\%). About one-fourth of our sample firms $(27 \%)$ were driven by liquidity concerns, and about the same number $(20 \%)$ intended to use their shares as a currency for acquisitions. Surprisingly few firms mentioned as motives a higher valuation $(7 \%)$ or the desire to increase exit opportunities by becoming an attractive target for acquisitions $(0 \%)$. 
When asked about realized (as opposed to expected) benefits, almost half the foreign firms $(47 \%)$ discovered that they could use their shares as currency for acquisitions. This represented more than twice as many as had expected to derive this advantage from listing on a foreign exchange. By contrast, firms that hoped for increased liquidity seem to have been disappointed; only $7 \%$ noted it as a realized benefit.

These results shed interesting light on the frequently mentioned motives for public listing. Apparently, some of these motives matter more for non-domestic firms than for domestic companies. And the differences in importance that entrepreneurs attach to these motives can be substantial.

\section{Costs and risks to entrepreneurs of listing their firms on a foreign exchange}

The benefits of listing on foreign exchanges have to be weighed against the costs and risks of taking an IPO to these markets. We consider these costs under five headings, paying particular attention to whether these costs might be different for non-domestic as compared to domestic entrepreneurial firms:

\section{Under-pricing and dilution}

The reasons for under-pricing cited in the literature include the winner's curse, ${ }^{13}$ the market feedback hypothesis, ${ }^{14}$ and the bandwagon hypothesis. ${ }^{15}$ These explanations are based on the existence of asymmetric information (or behavior) among various investors; they assume that there are informed and uninformed investors. In addition, they assume that the degree of asymmetric information between the issuing firm and the average investor does not vary.

Do the theories mentioned above predict differential under-pricing of domestic and non-domestic firms? And, if yes, what is the relative magnitude of the under-pricing? First, consider that the degree of asymmetric information between issuers and investors could be bigger for non-domestic than for domestic firms, because, for example, the evaluation of information given by non-domestic firms might be more difficult than the evaluation of the same information given by domestic firms. Following George Akerlof's adverse selection logic, this implies that the average quality of foreign issues will be lower than the average quality of domestic issues, as relatively more excellent foreign 
issues than domestic issues would tend to stay away from a market in which they do not receive a fair valuation. ${ }^{16}$ Since the ratio of "bad" to "good" firms will be higher for foreign than for domestic firms, the winner's curse and the bandwagon hypothesis would predict greater under-pricing of foreign than domestic IPOs.

However, if there are reasons that would lead us to expect that the average quality of foreign firms seeking listing is higher than the average quality of domestic firms, then, based on the above theories, we would expect smaller under-pricing of foreign firms as compared to domestic firms. For example, very promising, rapidly growing foreign firms may not really have the choice to list on their domestic capital markets when the latter are too small to enable these firms to raise sufficient capital to fuel their rapid growth. In those cases, high-quality issues could find their way to global capital markets for entrepreneurial firms. Another argument that would lead to the same conclusion is that the cash costs (see below), as well as the opportunity costs, of going public (e.g. management time spent traveling) are higher for non-domestic firms, hence only those firms that are doing exceptionally well will incur these costs.

\section{IPO costs}

There are direct costs of undertaking an IPO that are non-trivial. The cash costs of going public include underwriting fees paid to the investment bankers (usually 7 percent of the total offering amount), filing fees (e.g. the Securities and Exchange Commission charges $\$ 92$ for each $\$ 1 \mathrm{~m}$ raised), listing fees (e.g. \$100k-\$155k for Nasdaq, depending on the number of shares offered), legal and accounting fees (typically $\$ 500 \mathrm{k}-\$ 1 \mathrm{~m}$ in the United States), printing expenses for the prospectus (typically $\$ 200 \mathrm{k}-\$ 300 \mathrm{k}$ ), costs incurred for the roadshow (typically $\$ 100 \mathrm{k}$ ), directors' and officers' insurance (typically $\$ 500 \mathrm{k}-\$ 1 \mathrm{~m}$ ), and other cash fees (e.g. for consultants, press conferences, etc.). ${ }^{17}$ To these cash costs we must add the opportunity costs of management time spent on building and improving investor relations. Given the need for international travel and the barriers to intercultural communication, ${ }^{18}$ these opportunity costs arguably are higher for foreign than for domestic firms. Our survey suggests that these costs are often underestimated.

Some of these costs are fixed, so that for small issues the proportional cost of going public (as well as that of secondary offerings) can be quite high. Entrepreneurs compare the costs of going public on various 
exchanges (including their domestic one), and, to the extent that the costs might be lower on a foreign than on a domestic exchange, they might prefer a foreign listing. One American firm in our sample, for instance, chose to list on the Neuer Markt rather than on Nasdaq chiefly because it had hoped to take advantage of lower listing costs.

\section{Reporting requirements and other recurring costs}

Further costs to be considered in going public include the potential costs of litigation, as well as recurring disclosure requirements (e.g. quarterly reports, audits, shareholder meetings), which some firms can only meet by hiring additional personnel (usually one or two new employees to take care of investor relations). The disclosure of company-specific information may also entail indirect costs by inviting imitators and attracting product market competition. ${ }^{19}$ The increased scrutiny exercised by public shareholders can lead to a (perceived) loss of control and flexibility, and dealing with board issues can be perceived as timeconsuming and costly. Other recurring costs include listing fees, fees for auditors, and fees for market makers.

\section{Risk of negative spillover from failure of the exchange}

Companies listing on a foreign exchange also face the risk that a new exchange might develop a negative reputation, and that this reputation will spill over to the listed companies. This was actually the case for Germany's Neuer Markt, which ceased to exist in 2002. Although the risk of negative reputation spillover is difficult to assess ex ante, it is clearly higher for newer exchanges than for more established ones with higher trading volumes and more stringent listing requirements. Conversely, to the extent that the domestic market for public entrepreneurial finance is new, and the respective foreign market is relatively more established, domestic firms might choose to move to a foreign market that is perceived to be more stable.

\section{Employee tax penalties}

There may be special tax penalties for employees of firms listing on a foreign exchange. For example, employees of Canadian firms listing in Canada get the first CA $\$ 500,000$ of capital gains tax-free, but do not so if their company lists only abroad (e.g. in the United States). Listing abroad thus imposes a tax cost on the firm's employees who own company shares. 


\section{Globalizing entrepreneurship and venture capital}

The data presented in this chapter clearly suggest that looking beyond domestic capital markets and tapping foreign equity capital markets is a viable alternative for some entrepreneurial companies. The data further suggest that entrepreneurs must carefully examine the tradeoffs in choosing whether to list on a domestic or on a non-domestic capital market. Tradeoffs are of three types: financial tradeoffs, specifically costs (cash costs, opportunity costs) versus benefits (amount of capital raised, trading volume, valuation); strategic tradeoffs, for which the costs of competition and imitation must be weighed against the benefits of legitimacy and credibility; and a third group, which can be considered entrepreneurial (i.e. company development). Here, the cost of the loss of focus on developing the company must be weighed against the benefits of increased opportunities for growth, both financial and in markets.

Our analysis suggests that the factors that seem to make globalizing entrepreneurs prefer a foreign listing to a domestic one are often strategic and organizational in nature. Many founders hope to raise the company's visibility in foreign product and factor markets both by raising equity in these markets and by establishing relationships, trust, and track records with foreign investors, investment banks, and institutions. In addition, a substantial number of entrepreneurial firms that (plan to) operate internationally have adopted, or strive to adopt, an international image. While being rooted (e.g. headquartered) in a specific country, these entrepreneurial firms consider themselves multinational (e.g. pan-European rather than Dutch). By listing on a foreign exchange, they seek to enhance and make consistent their chosen corporate identity. These considerations confirm our belief that the emergence of global capital markets for entrepreneurs documented in this chapter goes hand in hand with broader trends toward globalizing product and factor markets.

Some companies have chosen a dual listings approach; that is, they have floated their securities, either simultaneously or sequentially, on both domestic and non-domestic capital markets. This approach, while more costly, enables companies to enjoy the potential benefits of a domestic listing, such as offering domestic investors easy access to the company's securities and providing employees with potential tax benefits, while at the same time enjoying the fruits associated with a foreign listing discussed above. 
The emerging trend of globalizing public capital markets, which we documented in this chapter, has implications for private equity markets as well. Anticipating the possibility of exiting their investment in global capital markets, many private equity firms have opened branches or developed co-investment partnerships in non-domestic capital markets, thereby providing additional sources of capital to aspiring entrepreneurs. For example, over 340 leading US firms have an Israeli, European, or Asian focus. ${ }^{20}$ These funds source investments globally and inject managerial and financial discipline early on in the development of the company. This discipline, coupled with the venture capitalists' knowledge of the US capital market, gives the investee firms easier access to the US public market. Hence there is an externality in the capital formation process for entrepreneurial firms: the opening of public markets to non-domestic firms makes it attractive for domestic private equity investors to make foreign investments. These investments, in turn, make it easier for the investees to access foreign public capital markets.

The emergence of global private and public capital markets for entrepreneurial firms is likely to accelerate the pace of commercializing innovations, and contribute to job creation and economic development. Furthermore, despite the overall slowdown of domestic venture capital and private equity investments since the peak year of 2000 when $\$ 94.4$ billion were invested by US-based firms in 6,142 domestic and foreign transactions, ${ }^{21}$ the globalization of US private equity firms continues. This trend, in turn, points to the expectation of investors that once the public market for young, emerging growth firms reopens, non-domestic firms will be able to gain access to the public market as well.

\section{Notes}

1 See, for example, A. Blass and Y. Yafeh, "Vagabond Shoes Longing to Stray: Why Foreign Firms List in the United States," Journal of Banking and Finance, 25(2001), pp. 555-572; and C. S. Eun and S. Sabherwal, "Cross-border Listings and Price Discovery: Evidence from US-Listed Canadian Stocks," Journal of Finance, 58 (2003), pp. 549-576.

2 The analysis examined the ten-year period 1988-1998, as well as the thirteen-year period 1988-2001, so as to control for the period considered by some to be a bubble in capital markets. 
3 Data regarding IPOs on Nasdaq were collected from SDC Platinum, CRSP, Dealogic LLC, the Nasdaq website, and Compustat. Obtaining data on foreign IPOs on the Neuer Markt was more problematic as there is no central data depository. (Note that companies that transferred from another exchange are not included in the IPO count as they were already publicly listed. We excluded thirty-six companies from the NM analysis because of a former listing on another exchange or a lack of data.) Specifically, we obtained stock price and market-value data from Datastream, while other data were extracted from company filings that were available on the NM website and, in some cases, from the filing prospectus. For example, the issue price and the country of origin were obtained from the NM website and from the companies' filings. As the NM IPOs were in a foreign currency (either the DM or the euro), we converted the IPO listing price into US dollars using the inter-bank exchange rate on the day of the offering.

4 The age data on NM companies excludes eighteen companies because of a lack of information.

5 J. R. Ritter and I. Welch, "A Review of IPO Activity, Pricing, and Allocations," Journal of Finance, 57 (2002), pp. 1795-1828.

6 This is based on open-ended questionnaires sent to forty-four foreign firms who listed on the Neuer Markt; fifteen questionnaires were returned (giving a response rate of 34 percent). The questionnaires were completed in most cases by the firms' chief financial officers.

7 B. S. Black and R. J. Gilson, "Venture Capital and the Structure of Capital Markets: Banks versus Stock Markets," Journal of Financial Economics, 47 (1998), pp. 243-277.

8 Ritter and Welch, "Review of IPO Activity," p. 1796.

9 A. L. Stinchcombe, "Organizations and Social Structure," in J. G. March (ed.), Handbook of Organizations (Chicago: Rand-McNally, 1965), pp. 142-193.

10 P. Schultz and M. Zaman, "Do the Individuals Closest to Internet Firms Believe They Are Overvalued?" Journal of Financial Economics, 59 (2001), pp. 347-381.

11 L. Zingales, "Insider Ownership and the Decision to Go Public," Review of Economic Studies, 62 (1995), pp. 425-448.

12 T. Chemmanur and P. Fulghieri, "Investment Banker Reputation, Information Production, and Financial Intermediation," Columbia First Boston Series in Money, Economics and Finance working paper, no. FB-91-09.

13 In an IPO, a fixed number of shares are typically sold at a fixed price. If demand exceeds supply, rationing will occur. Assume there exists an asymmetry of information among investors. If the "less informed" 
investors get all they ask for, that is because the more informed investors did not want the shares. Faced with this adverse selection issue, the less informed will only submit purchase orders if, on average, the issue is sufficiently discounted to compensate them for the bias in the allocation of new issues.

14 To induce the true revelation of an investor's valuation of the stock of a particular IPO, the investment bankers compensate the investor through under-pricing. Further, the investment banker must underprice issues for which favorable information is revealed by more than those for which unfavorable information is revealed.

15 Investors pay attention not only to information about the company in which they invest, but also to whether other investors are buying. If no one else buys, then an investor may not buy, even if she has favorable information.

16 G. A. Akerlof, “The Market for 'Lemons': Quality Uncertainty and the Market Mechanism," Quarterly Journal of Economics, 84 (1970), pp. 488-500.

17 J. A. Fraser, “The Road to Wall Street," Inc., 24, 6 (2002), pp. 80-85.

18 One Dutch company that listed on Neuer Markt, for example, stated that "Germany has a completely different culture on investor relation-related activities than the Anglo-Saxon countries." As investors in small- and mid-cap stocks preserve a local (i.e. national) investment focus, a foreign company "has to attract the national financial press."

19 V. Maksimovic and P. Pichler, "Technological Innovation and Initial Public Offerings," Review of Financial Studies, 14 (2001), pp. 459-494.

20 Source: Venturescape (http://www.venturescape.com/).

21 Source: Venture One (http://www.ventureone.com/). 
